\title{
Determinants and development of companies created through the UE projects on the example of selected people groups
}

\author{
Autor: Błażej Suproń
}

\begin{abstract}
The role of micro-enterprises in the economy is invaluable. Their growth contributes to the increase of human capital, and influences necessary changes in the employment structure. Conducted research involved two groups of project participants, who took part in analogical projects. The first group consisted of people who had finished their education up to the age of 30, and the second group consisted of people aged above 50. The conditions for participation were the age criteria and having an unemployed person status. In the research, mostly statistical methods and the questionnaire method were used, consisting of presenting the participants with a specifically designed survey. The main aim of the research was to identify the main barriers of development of the established enterprises, and verification of the number of enterprises that decided to continue their commercial activity after the obligatory period imposed by the project. The results of the research constitute a different observation that the previous researches which have shown that it has been mainly people over 50 years old which were characterized by a higher risk than young people. At the same time, the received results may find use in future programs concerning promoting entrepreneurship of excluded people, and also better fit those projects to their needs. The need of conducting broader analysis covering a larger number of project participants from various regions, should also be considered.
\end{abstract}

Keywords: Subsidies, Enterprises, Growth, New businesses

JEL: H81

\section{Introduction}

In his best-selling publication, Donald Trump stated that entrepreneurship starts with a vision, and that nothing significant can ever be created
History: otrzymano 2016-02-16, poprawiono 2016-05-25, zaakceptowano 2016-05-26

without a vision, whereas the effects of entrepreneurship are the outcome of imagination, hard work, dedication, and willingness to accept reasonable risk (Gordon and Trump 2014: 19). 
Promoting entrepreneurship due to its economic and social impact is extremely important. Although a number of programmes have been in effect for several years now, including outreach programmes for encouraging people to start their own businesses, we are still lacking in detailed studies on the effectiveness of such projects. This stems from the fact that project teams usually analyze parameters according to the enforced methodology aimed at obtaining indicators necessary for the financial settlement of the project. At the same time, the effectiveness of EU projects after the end of the period for which the aid was granted is still not sufficiently monitored (Szwabe, 2007: 271-272).

It is crucial not only to encourage people to take economic initiatives but also to provide opportunities for their further development after the main de minimis aid has stopped. In the face of other, not so favorable factors determining the development of entrepreneurship, the aid in the form of EU funds itself may lead to the inefficient use of previous grants. It is also important to provide space in which new businesses may be set up on preferential terms and with access to the basic infrastructure. Stimulating all of these factors is very complex, and omitting even one of the determinants may cause barriers.

The aim of this study was to analyze the beneficiaries and the results of the support they received from projects financed from the European Social Fund (ESF) funds. These projects were implemented in 2014 as part of the Human Capital Operational Programme, Measure 6.2 - The labor market open for all.

The first project involved full support for people planning to start and run a business. It was addressed to those residing in the counties of Goleniów and Police and the city of Szczecin who were at least 50 years old and were professionally inactive. The project provided for the aid in the amount of PLN 40,000.00 for starting a business and PLN $1,500.00$ of a monthly subsidy for the first six months of running the company.

The second project was designed for people aged under 30 and without employment, i.e. the unemployed and/or the professionally inactive, living in the counties of Goleniów, Police, and Kołobrzeg. The project awarded a grant in the amount of PLN $30,000.00$ for starting a business and PLN 1,270.00 of a monthly support for the first six months of running the company.

\section{Literature review}

It is commonly believed that the forerunners of entrepreneurship include Adam Smith, I.B. Say, and J. Schumpeter. The term entrepreneurship appeared for the first time at the turn of the 18 th and 19th centuries. The reasons for using this term were the industrial revolution and the emergence of new forms of governance and management at the time. The first one to clarify the concept was $\mathrm{R}$. Cantillon in his book Essai Sur la Nature du Commerce en Général. To him, entrepreneurship meant noticing the opportunities created by the market (Karlof 1992: 19).

The owner's prior personal entrepreneurship is a necessary prerequisite of economic entrepreneurship marked by setting up one's own business. This is a complicated sociological and psychological category, which, however, relates not only to business. In today's pursuit of success, personal entrepreneurship is needed in every human activity, and therefore it is not limited only to economic entrepreneurship (Matejun 2015: 4).

Tadeusz Kotarbiński identifies personal entrepreneurship as a trait of a man of initiative perceived as someone active and full of energy and 
who spontaneously and energetically undertakes and starts the implementation of various plans. The idea is not to wait for someone's orders or push but to initiate new, important, and useful projects yourself in a creative and vigorous manner. Hence, the characteristics of a resourceful person clearly affirmed by T. Kotarbiński include initiative and vigor which both give rise to and trigger intentions and make the original ideas more realistic (Borowiec 2011: 41-42).

The development of entrepreneurship is a priority for countries of the former communist bloc, where the socialist economy led to a permanent degeneration of the entrepreneurial spirit. As a result of the transition from the centrally planned economy to free market, new rules and conditions for businesses took effect in a very short time. Because the private sector was marginalized and extremely limited, a number of changes introduced after 1989 made it necessary to operate in the market economy. At the same time, the economic life began to be governed by the rules of supply, demand, and work for the profit of enterprises (Zioło and Rachwała 2012: 375).

In her analysis of the political transformation in Poland, Barbara Olszewska (1999) refers to the economic mentality of a post-communist mas as "statist". "It is expressed in an unwillingness to individual entrepreneurship, in giving up economic sovereignty, and in inability to take action at one's own risk. Counting on the state and being completely dependent on the state is still a prevailing attitude" (38).

The main problem of businesses of the communist economy was excessive employment and extreme energy consumption caused by the inefficient use of manpower. As a result of the decline in demand as well as the resulting restructuring, the beginning of the 1990s was marked by mass layoffs and rising unemployment, especially among low-skilled workers of large state-owned enterprises who found it difficult to cope in the free labor market (Pfirrmann and Walter 2002: 308-310).

Today, this situation is particularly true for people over 50 who lived in the communist economy and because of that have failed to develop proper attitudes in terms of entrepreneurship and self-realization. The $50+$ population includes people born in the wartime period of demographic decline as well as the post-war baby boomers. Due to the availability of data, the analysis of the size of this generation at birth is limited to people born after World War II, in the years 1946-1965 (Rynek pracy a osoby bezrobotne 50+ 2014).

Currently, the 50+ age group represents $35.7 \%$ of the Polish population; however, according to the forecasts of the Central Statistical Office of Poland (GUS), this share will have risen to $50 \%$ by 2040 . It will be reflected in a significant increase in the old-age dependency ratio. The above-described process of population aging co-occurs with the phenomenon of socio-economic transformation. These changes have especially affected and continue to affect people over 50 (Sytuacja osób bezrobotnych w wieku 50+ na lokalnym rynku pracy 2014).

Poland's basic problem is that it has one of the lowest employment rates among mature people in Europe. What we can also observe is the deterioration of their position in the labor market, leading to a greater risk of unemployment and professional inactivity than in other age groups, which in turn may cause marginalization of this age category and their exclusion from social life. People aged 50 and older are in a particularly difficult situation in the labor market and have to face serious problems affecting their professional activity. These problems relate to their professional 
potential (unsatisfactory scope and level of skills in modern technology and foreign languages) as well as to their job and spatial mobility.

At the end of 2014, people over 50 accounted for $26.0 \%$ of all the registered unemployed, compared to $24.3 \%$ a year earlier. It is worth noting that in late 2005, this group constituted less than $16 \%$ of the registered unemployed, which means that within a few years this number increased by more than 8 percentage points. At the same time, in the face of unfavorable forecasts and a high unemployment increase rate in older age groups, we have seen a slow but steady growth of labor market participation and employment among people above 50 years of age.

In 2014, the number of employed people aged at least 50 increased by $111,000(2.6 \%)$ to $4,419,000$ people. The employment rate in this group rose from $31.8 \%$ to $32.4 \%$, i.e. by 0.6 percentage point, compared to an increase of 1.1 percentage point in the group aged 15 and older (Fig. 1). This means that the increase in employment among older age groups was not the main factor contributing to the general boost in employment (Osoby powyżej 50 roku życia na rynku pracy w 2014 r. 2015).

The analysis of the registered unemployment concerning the unemployment group of people over 50 years old in the West Pomeranian voivodeship in the years 2005 - 2014, allows to divide this period into three stages, namely a decrease of registered people up to 2008, a constant increase in the following years up to 2013, and the last stage, the year 2014, with a decrease in reference to the previous year (of about 3,7 thousand registered people). The tendency of changes in the number of unemployed people which are over 50 years old, is analogical to the direction of the changes in the unemployment in the West Pomeranian voivodeship in that time period.

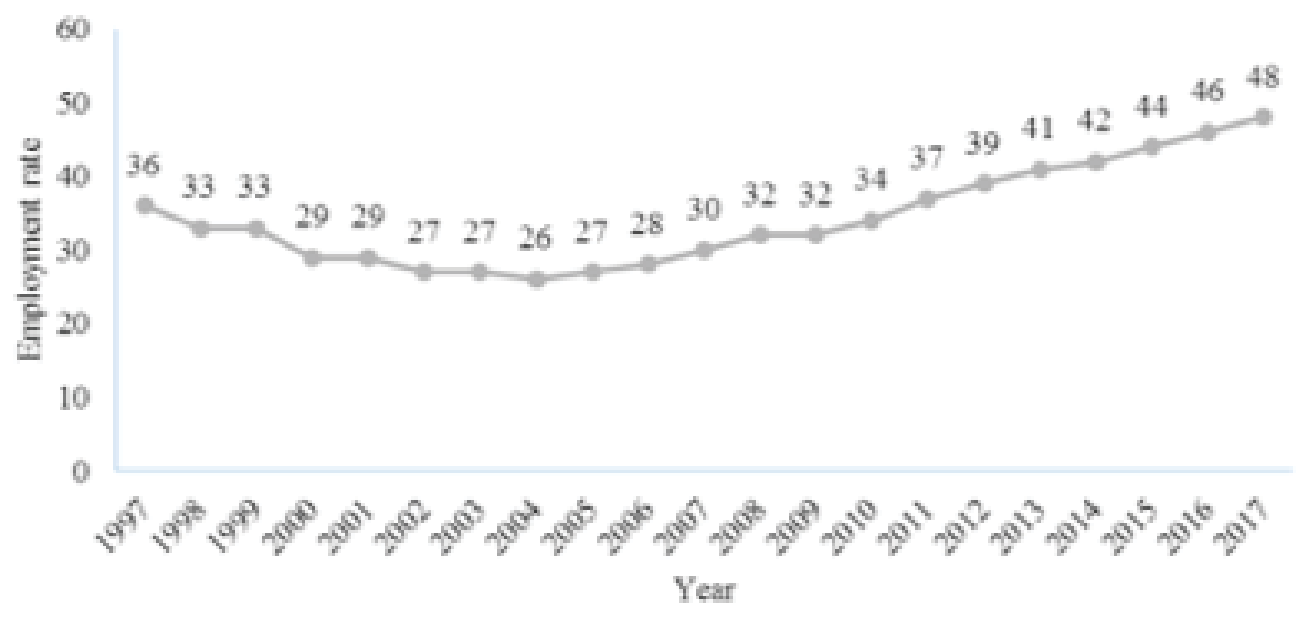

Figure 1. The employment rate in the age group 55-64, in the years 1997 to 2014, and forecasts for the years 2015 -2017 in Poland 
However, the case is different when it comes to the number of these unemployed people in the overall number of the unemployed, because despite the decreases and increases in the overall number of unemployed people after 2005 , the number of those over 50 , grew. At the end of 2005, unemployed people after 50 constituted $18,3 \%$ of all the registered unemployed in that voivodeship, and $29,6 \%$ at the end of 2014 (Kalejdoskop zachodniopomorskiego rynku pracy 2015).

Another group with a difficult position in the labor market is young people. This issue is crucial from the point of view of economic and political stability of Poland. Because the category of young people is heterogeneous, there are three usually distinguished age groups representing people up to the age of 30 (Gontarek, Politańska and Stanisławski 2013: 2):

- high-school students, aged 16-19;

- university students, aged 19-25;

- graduates, young workers, aged 25-30.

Along with the unemployed $50+$, the long-term unemployed and the disabled, the unemployed aged under 25 are people in a very peculiar situation in the job market. The GUS data on the Polish labor market show that despite their good education and high skills, they have to cope with a lot of difficulties during the process of entering the labor market and getting employed.

It should be noted that in the years 1993-1995, there was the highest number of young people registered in labor offices - more than 900,000 , with some quarters exceeding 1 million. Also at this time, the share of young people in the total number of registered was high too, reaching as many as $34.5 \%$. Then, the process of decline lasted until the end of 2007, when the young accounted for $19 \%$ of the unemployed registered in labor offices. In late 2008, the number of young unemployed registered in labor offices totaled 304,500 (Sytuacja na rynku pracy osób młodych 2014). In 2014, there were 2,829,000 economically inactive young people, accounting for $20.9 \%$ of all the economically inactive $(13,543,000$ people). The employment rate of people aged 15 and above increased in 2014 to $51.7 \%$, equaling $24 \%$ among people aged $15-$ 24 (Fig. 2).

In 2014, the majority of the young unemployed had post-secondary and secondary vocational education $-83,200$ people $(27.6 \%$ of all unemployed under 25). There were 131,100 young people with basic vocational education, junior high school education and below (43.4\%). 62,400 young people had secondary high-school education (20.7\%), while 25,200 had higher education (8.4\%).

There were more than 17,4 thousand young people in search of work in the West Pomeranian voivodeship in 2014, which constituted $15,7 \%$ of all of the unemployed. Analyzing the structure of the unemployed up to 25 years old, it can be determined that in that category most people had a junior high school education or lower - $32,2 \%$, more than a half had absolutely no work status $-51,8 \%$, and most people remained registered for 1 to 3 months $-27,7 \% .5,8 \%$ of young unemployed people declared a higher education. At the same time, an improvement in the conditions of this particular group has been observed, mainly thanks to activation operations financed from European funds (Bezrobocie osób do 25 roku życia w województwie zachodniopomorskim w 2014 2015).

The above issues related to the employment of the young and the elderly are also observed in other European Union countries. During the recent economic crisis in Western Europe, these groups of workers were affected by the redundancies (Tremme 2010: 91). 


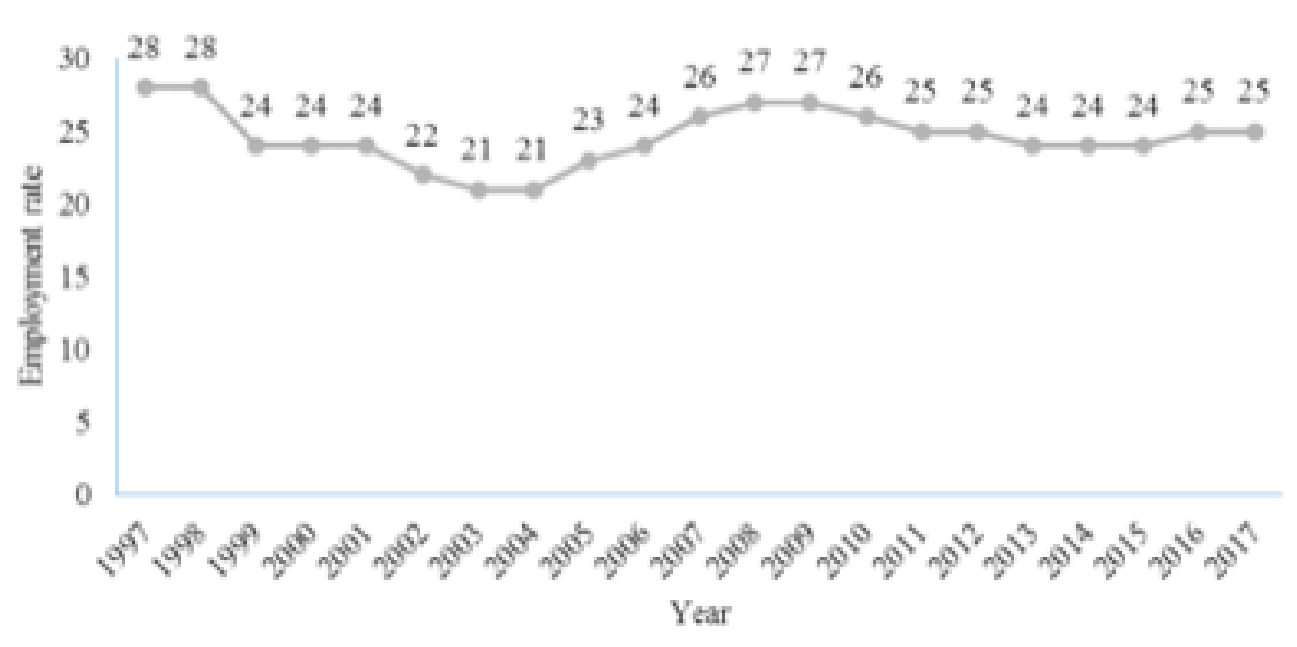

Figure 2. The employment rate in the age group 15-24, in the years 1997 to 2014, and forecasts for the years $2015-2017$

Source: own study based on Eurostat.

Most countries are aware that supporting the development of entrepreneurship is one of the elements of labor market development. The improvement of entrepreneurship is essential to achieve intelligent and sustainable growth promoting social inclusion, which is the objective of the strategy "Europe 2020". It is primarily a way to cope with the new economic challenges, to create jobs, and combat social exclusion in the group of young people and people over 50 .

In view of the results of the global financial and economic crisis in the policy of economic and social development, individual countries have put a greater emphasis on entrepreneurship and self-employment. This is particularly important for young people, who find it more difficult to enter the labor market and start their professional career. In addition, people in the group of 50+ have the opportunity to use their prior experience to achieve higher incomes and stable employment (Przegląd polityk i programów rozwoju przedsiębiorczości sprzyjających włączeniu społecznemu 2015).

Individual companies are the foundation of economy, stabilizing and supporting economic growth. These entities are strongly associated with the region where they operate and are able to use creativity, strengthening their market position. Efficient entrepreneurship contributes to a better economic position of regions and enhanced competition.

The significance of the development of entrepreneurship has been emphasized in the policy of the European Union as the most important determinant of the further socio-economic development. It is one of the elements of the broadly-defined concept of the knowledge economy, on which the EU economic and social policy is based (Szpon 2013: p.18). 
In the economy of the European Union, supporting small enterprises plays a key role in the harmonious socio-economic growth. Economic literature generally emphasizes that the development of micro entities boosts the efficiency of the labor market and prevents exclusion (Huczek 2008: 9-10).

A series of initiatives aiming at the development of entrepreneurship in Poland have been possible thanks to the financial support granted under the European Funds. Due to the fact that the Polish economy had to be adapted to the economies of Western Europe, significant resources were allocated from the EU funds in the form of aid programs which provided the following types of support (Kopczuk and Proniewski 2006: 213-214):

- direct support in the form of EU programs;

- indirect support in the form of national programs co-financed from the Structural Funds for SMEs and business environment institutions;

- financial support, including grants, loans, and collaterals;

- non-financial support in the form of services: support for business, consultancy, information.

Out of these forms of support, Structural Funds are key instruments for promoting entrepreneurship. Their statutory purpose is to support the restructuring of the economy, primarily by reducing disparities between the levels of development of individual regions. As part of these activities, the following four Structural Funds were established:

- European Social Fund (ESF);

- European Regional Development Fund (ERDF);

- European Agricultural Guidance and Guarantee Fund (EAGGF);

- Financial Instrument for Fisheries Guidance (EIOR).

At the same time, the most important program that covers the majority of citizens is the European Social Fund
(ESF). Its financial resources are invested in people, particularly those who have difficulty finding work. As in the case of the researched projects, these resources may be used in the form of grants for particular categories of people in order to help them enter the job market.

Support in the form of subsidies for starting an own business do not always give the desired results. According to the conducted researches related to evaluating projects for the unemployed in the budged perspective 2007 - 2013, $68 \%$ of companies on a national scale, remain on the market after 2 years from registration, but a year later that number drops to $56 \%$. At the same time, the analysis of potential factors influencing the survivability of companies established thanks subsidies, showed on a national scale that there is a higher risk of closing the business by people who were unemployed for a longer period of time before participating in the project (at 18\%), by people younger than 25 years (at $42 \%$ ) and by people 55 years old or older (at 60\%). Moreover, people with higher education established businesses of a higher survivability than the rest, and the risk of them ceasing their businesses was lower (Badanie skuteczności wsparcia realizowanego $w$ ramach komponentu regionalnego PO KL 2007 - 2013 2013).

\section{Research methods}

In order to determine the research sample, data from the Voivodeship Employment Agency concerning projects connected to activation of the unemployed in 2014, were used. The main criteria for determining the research group were the following factors:

- The project must be in the course of execution,

- Participants of various groups vary in age, 
- Initial classification of the participants in formal terms has been carried out,

- At the moment of starting the research, trainings take place,

- There is access to project data, such as business plans or the participants' statistical data.

Assuming the above mentioned criteria, two projects which meet the research assumptions have been determined. At the same time, in the groups defined for the research, a full test which included all of the participants of the project, has been used.

The research group consisted of people who passed the preliminary procedure and qualified for support in the form of cash and monthly subsidy for opening and running a business. As part of the project, the beneficiaries also took part in training and consultancy on the basic principles of running a company.

Therefore, the research participants successfully passed the initial content-oriented assessment of their business plans in terms of whether they meet the requirements for participation in the project, which was carried out in accordance with project guidelines. The sample included 41 respondents, including 16 people aged under 30 and
25 people aged over 50 . The oldest research participant was 61 years old, while the youngest was 24 years old. A detailed description of the group is presented in Table 1.

In the research, statistical and documentation methods were used. A survey was administered as a complementary method. The research material consisted of business plans, statistical data, data from the Polish Central Register and Information on Economic Activity (CEIDG), the survey, and project documentation.

\section{Analysis and discussion}

The first part of the research was the analysis of the reasons why the respondents decided to open their own business. The vast majority indicated that they were participating in the project because they were having trouble finding a job. A separate group of participants pointed out their dissatisfaction with their previous work as the main reason (working below their qualifications). At the same time, 22 of them were people aged 50+.

As their main motivation, young people usually indicated difficulty finding a job. This result confirms the general trend in the Polish economy where

Table 1. Characteristics of the study group due to the project

\begin{tabular}{|c|c|c|}
\hline Feature & Group to $\mathbf{3 0}$ years of age & Group over $\mathbf{5 0}$ years of age \\
\hline Number & 16 & 25 \\
\hline Min age & 24 & 50 \\
\hline Max age & 27 & 61 \\
\hline Median & 26 & 54 \\
\hline Average & 26 & 55 \\
\hline Dominant & 27 & 54 \\
\hline From city & 12 & 23 \\
\hline From the village & 4 & 2 \\
\hline Women & 16 & 15 \\
\hline Men & 6 & 10 \\
\hline
\end{tabular}




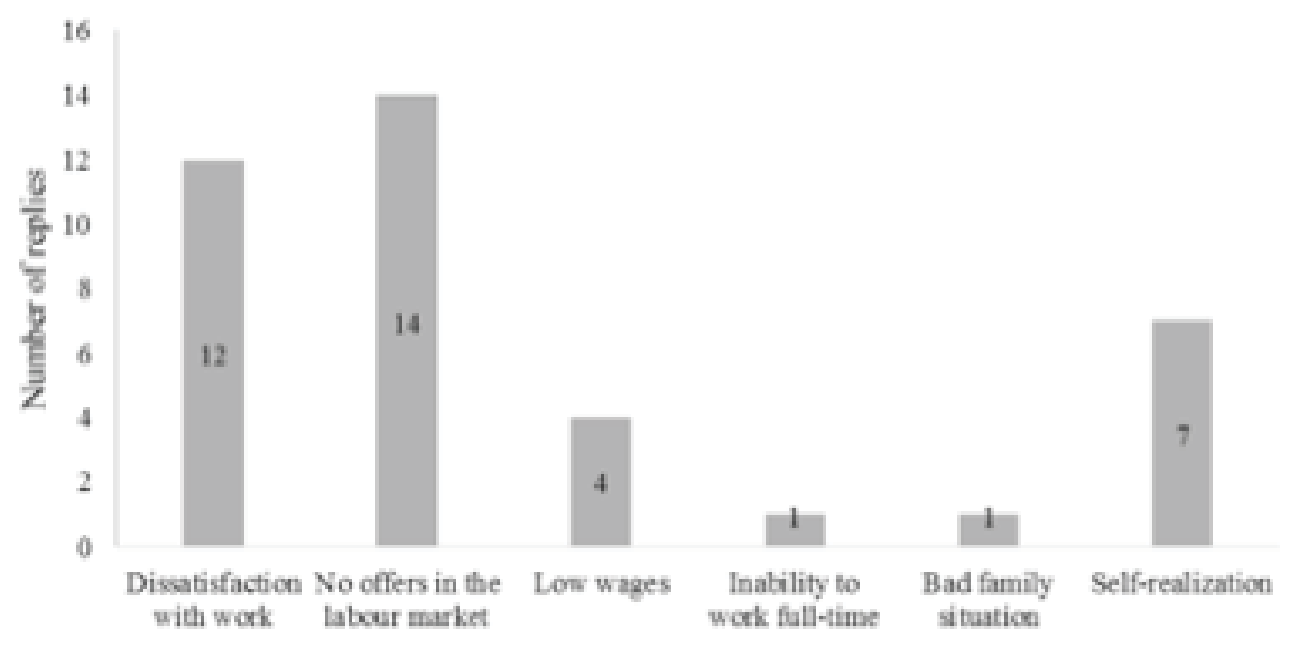

Figure 3. Reasons for undertaking the business of the subjects tested from tested groups

\author{
Source: Authors' research.
}

people from the researched groups experience extreme difficulties finding permanent employment (Fig. 3).

The above reason is related to another aspect of the research, which included verifying the previous experience and skills of people intending to run their own company. Exactly 21 people of the respondents indicated an employment contract as the type of their last employment, 9 said it was order contract, while 5 had run their own business in the past. The remainder of the people identified other forms of employment.

Among the young people, the prevailing form of their last employment was order contract. According to the study conducted by the Polish Agency for Enterprise Development (PARP), order contract or contract to perform a specified task is offered to almost every fourth young employee. For this age group, it can be an additional motivation to start a business. People bound by order contracts are usually at risk of low job stability and problems with obtaining a mortgage (Sytuacja młodych na rynku pracy z perspektywy przedsiębiorstw MŚP, 2014).

Most respondents aged $50+$ previously worked under a contract of employment, which is associated with longer work experience and higher skills. In this case, it is the loss of permanent employment that can be a major spur to owning a business.

It should be noted that nearly 14 people of the respondents remained unemployed for less than 3 months prior to the project, and 14 people had the status of an unemployed person for a period longer than one year. The vast majority of the long-term unemployed included people aged 50+. Young people remained unemployed usually for less than three months. This is due to their greater flexibility and mobility.

Another important aspect that was examined was the industry indicated according to the PKD code (Polish Statistical Classification of Economic Activities) provided in the application 
form. 8 respondents said that they were planning to set up a company in the construction industry, 9 people in trade, 17 people in the service industry, and 7 people in other sectors (industry, transport, hotels, and restaurants).

The collected material shows that 29 participants had prior work experience relevant for the business they intended to run. Among those who did not have previous experience, there was an equal distribution of the respondents over 50 and under 30 . It should be emphasized that opening a business without prior experience is risky due to the lack of adequate knowledge and skills.

In the second research stage, the beneficiaries indicated three obstacles which, as they believe, make it difficult to start and run a business. All the participants chose the lack of capital necessary to conduct the intended business activity. Other barriers were high social security (ZUS) contributions and market competition (Fig. 4).

One interesting observation is identifying the rate of compulsory social security and health insurance contribution for the self-employed as the potential obstacle. It should be noted that the Polish Act on the social security system provides for two types of contributions (Dz. U. of 1998, No. 137, item 887):

- Preferential rates primarily for the entrepreneurs only starting their own businesses. Reduced contributions are voluntary and are valid for the first full 24 months. The basis of calculation of the preferential social security contributions includes $30 \%$ of the minimum gross salary.

- Standard rates applying to the entrepreneurs who cannot benefit from the preferential rates. In this case, the basis of contribution calculation is $60 \%$ of the projected average monthly salary in the sector of private companies.

- The basis for the calculation of the health insurance contribution for the self-employed running a one-man company is $75 \%$ of the average salary in the corporate sector. What is a clear disadvantage in this case is the fact that the amount of contribution does not depend on the company's income criterion. Thus, each business owner has to pay the same amount of contribution regardless of his income and size of business. At the same time, as shown by countless studies, the basis of contribution calculation for micro-entrepreneurs is inflated. This is due to the methodology used by GUS to estimate the abovementioned basis which covers only companies employing more than 9 people (Informacja o sytuacji społeczno-gospodarczej kraju w styczniu 2015 r., 2015).

Since paying the contributions is mandatory, people running micro-enterprises have to incur a fixed cost regardless of the achieved income. In 2014 , the social security contribution amounted to PLN 716.99, while the health insurance contribution was PLN 270.40. For companies which do not have a significant number of customers, a monthly payment this high can be a major barrier to running a business.

The analysis of the business plans showed three main categories of expenditure that the grant would be spend on. Almost 35 people declared buying a car as the main expenditure, 20 people indicated that the funds would be used to buy machinery and specialist equipment, 10 respondents would spend their money on marketing, and 14 persons declared other expenses (renovation of the premises, hiring an employee, financing current operations). Only 1 person indicated that he/she intended to use the grant for the development of innovation. 


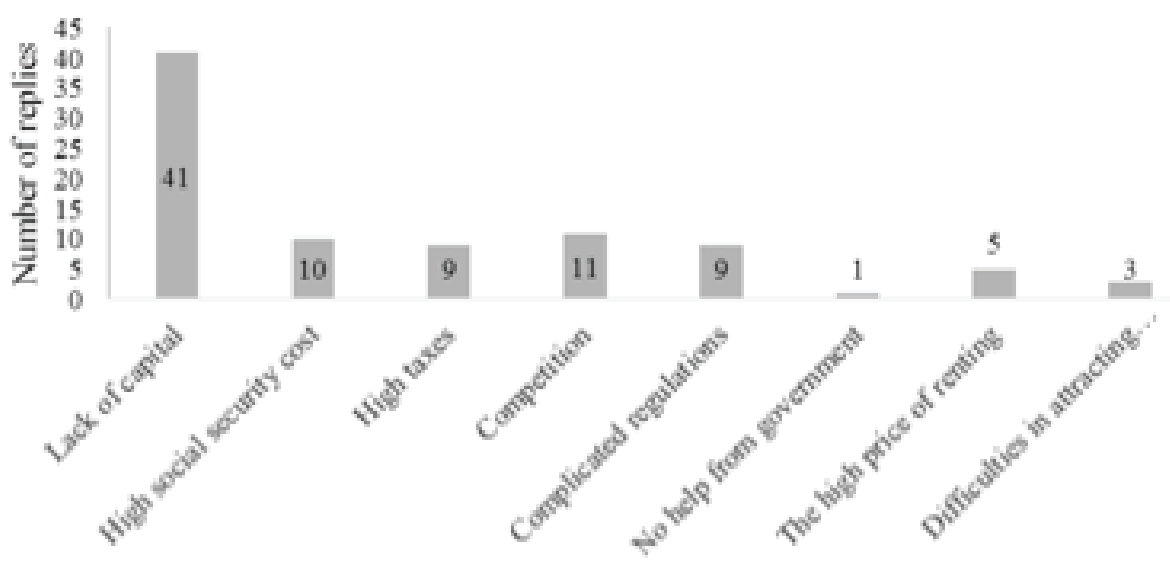

Figure 4. The problems of start-ups by respondents

Source: Authors' research.

Furthermore, the project participants shared their expectations with respect to the forms of support for entrepreneurship which they would like to benefit from in the future (Fig. 5). The main desired form of support included tax reliefs and help centers for entrepreneurs. Moreover, the respondents indicated that in the future they would greatly benefit from preferential loans, business meetings, and centers for business incubation. It is therefore important to continue to develop a network of business incubators, which largely meet the expectations of new companies.

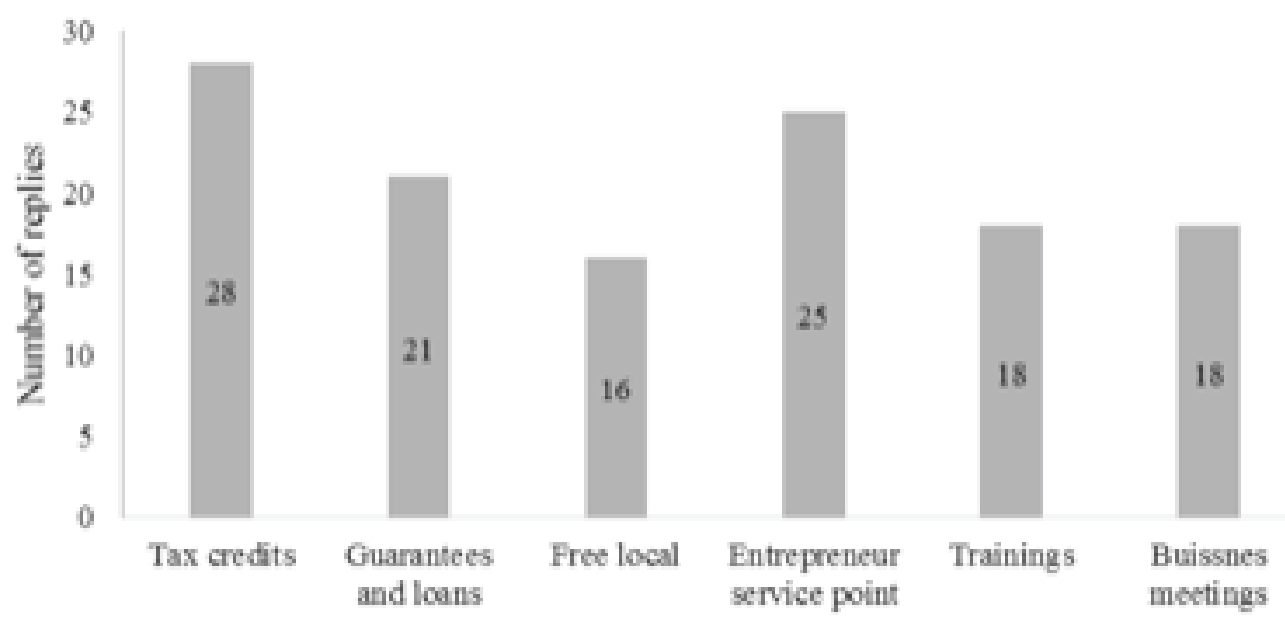

Figure 5. Desirable forms of support entrepreneurship by respondents 
Business growth and hiring employees is extremely important for a company. Therefore, the business plan analysis also focused on this aspect. Almost 21 of the respondents did not indicate a desire to hire anyone. At the same time, most people planning to hire staff indicated that they would use order contracts.

As factors discouraging them from hiring employees under the employment contract, the respondents most often chose high costs of employment and the provisions of the Labor Code which are to the employer's disadvantage.

In the last part of the research, the beneficiaries were asked if they believed that in 2012-2014 the conditions of setting up and running a business in Poland improved or not. Exactly 32 of the respondents answered that they see improvement in this area. At the same time, 33 people said the grant was as a major incentive for them to start a business, and 24 people admitted they were motivated by the preferential social security contributions in the first two years of running a company. What is interesting is that it was mainly people in the group 50+ who indicated the option to run errands via the Internet. Tax preferences in the form of exemption from VAT and the option of a quarterly tax return were indicated only by 10 participants. When examining the procedure for obtaining the grant from the European Union funds, 31 of the beneficiaries admitted that it was very complicated. The requirements laid down for EU projects include a lot of formalities that a beneficiary needs to comply with in order to be granted aid. Undoubtedly, attempts should be made to simplify these procedures, especially for people who have no previous experience in obtaining such aid. In the analyzed projects, the required period of running a business was 12 months. In order to assess the effectiveness of the aid after the end of that period, the researchers verified whether the beneficiaries' companies still operate. In the group of under 30 , 6 people closed their businesses with the end of the project period. In the $50+$ group, this percentage was considerably lower and amounted to 4 people. All business activity suspensions or closedowns occurred within the first month after the end of the period required by the project rules.

This constitutes a different observation as to the researches presented in the report titled "Badanie skuteczności wsparcia realizowanego $w$ ramach komponentu regionalnego PO KL 2007 - 2013" according to which people over 50 years old were characterized by a larger risk than young people. At the same time, no difference in the survivability of the businesses has been observed in reference to the sex of the participants. However, a significantly larger percentage of survivability concerned businesses performing mainly professional works. Thus, people who had specific abilities managed better than those declaring a higher education.

This should be a clear signal for the developers of similar projects in future programming periods. The obtained results indicate that it is necessary to analyze the competences of future beneficiaries in a much greater detail. The resulting data clearly show that people without previous experience could not cope without financial support. Thus, it can be concluded that financial support for such people is highly ineffective. It is also conceivable that a certain percentage of people applying for grants only counts on certain financial gains in the form of purchased assets and does not intend to conduct business any further. An interesting observation is that three project participants had run their own company with a similar name and place of business prior to the project. 
These companies were closed down before the project and re-established as part of the grant.

It is also worth underlining that according to general guidelines concerning the new budget perspective for 2014 - 2020, due to the low effectiveness of the subsidies, a wider scope of the loans has been provided. At the same time, it is noted that subsidies shouId be given only to those who show the ability to sustain their businesses: are motivated, have the predispositions and are able to individually or after receiving training-advising support, prepare an appropriate business plan. It can therefore be said that the aim of supporting the unemployed in the following periods should be employing them and not encouraging entrepreneurship.

\section{Conclusion}

Summing up the results, it should be concluded that providing financial support for new businesses does not always brings the expected results. Particularly alarming observations were found in the case of the group of people aged under 30 , where a considerable proportion of the new businesses was closed down after the required period had expired. In this

\section{Bibliography}

Badanie skuteczności wsparcia realizowanego $w$ ramach komponentu regionalnego PO KL $2007-2013$ (2013), https://www.efs.2007-013. gov.pl/AnalizyRaportyPodsumowania/ Documents/raport_skutecznosC_PAG_1_18092013.pdf - [online $18.09 .201 \overline{5}$ r.]

Bezrobocie osób do 25 roku życia w województwie zachodniopomorskim w 2014 (2015), case, people over 50 are doing much better.

The immediate closedown of a company after the project is an unfavorable relocation of funds. In future projects, institutions with funds should construct more restrictive forms of application verification in order to exclude those who do not have the necessary skills to operate within specific business profiles.

At the same time, attention should be also paid to other forms of supporting entrepreneurship, not only subsidies. The researched beneficiaries suggested the need to introduce broader tax reliefs and preferential loans. Another issue is organizing help centers where business owners could obtain support while running their companies. Fortunately, there are more and more such institutions today. However, one crucial barrier still remains, i.e. the rate of compulsory social security contributions, which was very often indicated as the primary obstacle to conducting a business. This is extremely important, because the beneficiaries of such projects usually run small-scale businesses and are very often self-employed. Additionally, high social security contributions lead to an excessive risk of insolvency when the income is too low.

https://www.wup.pl/images/uploads/ II_DLA_INSTYTUCJI/statystyka_analizy_badania/analizy_i_opracowania/2014/Bezrobocie_os\%C3\%B3b do_25_roku_\%C5\%BCycia_w_ wo je w \% C $\overline{3} \%$ B 3 dzt w i e zachodniopomorskim_w_2014_roku. pdf [online 18.09.2015 r.]

Borowiec, A. (2012). Badanie postaw przedsiębiorczych zwiqzanych z zakładaniem mikroprzedsiębiorstw w Polsce wśród studentów kierunków 
ekonomicznych, Zeszyty Naukowe Uniwersytetu Szczecińskiego nr 368(63), Szczecin, p. 41-42.

Gontarek J., Politańska J., Stanisławski P. (2013). Problemy ludzi młodych na rynku pracy, Forum Młodych Lewiatan, Warszawa, p. 2.

Gordon M.E., Trump D.J. (2014). Przedsiębiorczość, Onepres, Warszawa, p. 19.

Huczek M. (2008). Wspieranie rozwoju małych $i$ średnich przedsiębiorstw przez Unię Europejskq, Zeszyty Naukowe Wyższej Szkoły Humanitas, Sosnowiec, p. 9-10.

Informacja o sytuacji społeczno-gospodarczej kraju w styczniu 2015 r. (2015), http://stat.gov.pl/download/ gfx/portalinformacyjny/pl/defaultaktualnosci/5498/1/38/1/z06_info_i polrocze_2015_zakladki.pdf [online 18.09.2015 r.].

Kalejdoskop zachodniopomorskiego rynku pracy 2015,

https://www.wup.pl/images/uploads/ II_DLA_INSTYTUCJI/badania/gospodarka/Kalejdoskop_Zachodniopomorskiego_Rynku_Pracy_1_2015.pdf [online 18.09.2015 r.].

Karlof B. (1992). Strategia biznesu, Biblioteka Menedżera i Bankowa, p.18. Warszawa, Kopczuk A., Proniewski M. (2006). Pomoc finansowa Unii Europejskiej dla Polski, Wyższa Szkoła Finansów i Zarządzania w Białymstoku, Białystok, p. 213-214

Matejun M. (2015). Absorpcja wsparcia $w$ zarzq̨dzaniu rozwojem mikro, małych $i$ średnich przedsiębiorstw pojęcie strategiczne, Zeszyty Naukowe Politechniki Łódzkiej, 1194, Łódź, p. 4.

Olszewska-Dyoniziak B. (1999). Antropologia totalitaryzmu europejskiego
XX wieku, Wydawnictwo „Alta2”, Wrocław, p. 38

Osoby powyżej 50 roku życia na rynku pracy w 2014 r. (2015), http://www. mpips.gov.pl/download/gfx/mpips/ $\mathrm{pl} /$ defaultopisy/9267/1/1/2014\%20 50.pdf [online 18.09.2015 r.]

Osoby powyżej 50 roku życia na rynku pracy w 2014 r. (2015), stat.gov. pl/.../PW_osoby_pow_50_roku_zycia_na_rynku_pracy_2011.p/[online 18.09.2015 r.]

Pfirrmann O., Günter H. (2002). Small Firms and Entrepreneurship in Central and Eastern Europe, Springer Verlag Berlin Heidelberg, Berlin, p. 308-310

Przegląd polityk i programów rozwoju przedsiębiorczości sprzyjających włączeniu społecznemu, https://www. power.gov.pl/media/9050/Raport_ OECD_przedsiebiorczosc_mlodych. pdf [online 18.09.2015 r.]

Rynek pracy a osoby bezrobotne 50+ (2014), www.rynekpracy.pl/pliki/ pdf/3.pdf [online 18.09.2015 r.].

Sytuacja młodych na rynku pracy z perspektywy przedsiębiorstw MŚP (2014),

http://www.efl.pl/finansowanie/EFL MLODZI_PRACA_RAPORT_www.pdf [online $1 \overline{8} .09 .201 \overline{5}$ r.].

Sytuacja na rynku pracy osób młodych 2014, http://www.mpips.gov. $\mathrm{pl} /$ download/gfx/mpips/pl/defaultopisy/9158/1/1/SYTUACJA\%20NA\%20 RYNKU\% 20PRACY\% 200 SOB $\% 20$ MLODYCH\%20W\%202014.pdf [online 18.09.2015 r.].

Sytuacja osób bezrobotnych w wieku 50+ na lokalnym rynku pracy 2014, www.pup.poznan.pl/zalacznik/id/211 [online 18.09.2015 r.] 
Szpon J. (2013). Wspieranie rozwoju przedsiębiorczości w Unii Europejskiej, Wydawnictwo WSIE, Szczecin, p. 18.

Szwabe M. (2007). Zarzqdzanie projektami wspótfinansowanymi z funduszy publicznych: Planowanie i realizacja, Wolters Kluwer Polska, Warszawa, p. 271-272.

Tremmel J. (2010). A young generation under pressure, London School of Economics and Political Science, Warszawa, p. 91.

Ustawa z dnia 13 października $1998 \mathrm{r}$. o systemie ubezpieczeń społecznych t.j. Dz.U. 1998 nr 137 poz. 887.

Zioło Z., Rachwała T. (2012). Rola przedsiębiorczości w edukacji: Przedsiębiorczość - Edukacja, Nowa Era, Warszawa, p. 375.

Determinanty i rozwój firm tworzonych w ramach projektów unijnych na przykładzie wybranych grup osób

\begin{abstract}
Abstrakt
Rola mikroprzedsiębiorstw w gospodarce jest niezwykle istotna. Ich wzrost przyczynia się do powiększenia kapitału społecznego oraz wpływa na konieczne zmiany w strukturze zatrudnienia. W związku z tym w latach 20072013 w ramach wdrożenia Programu Operacyjnego Kapitał Ludzki, przeznaczono znaczne środki pieniężne na dotowanie nowych przedsiębiorstw. Rola programów była nakierowana głównie na pobudzenie osób bezrobotnych oraz należących do grup wykluczonych społecznie. Przeprowadzone badanie obejmowało dwie grupy uczestników projektów, którzy brali udział $w$ analogicznych projektach. Pierwsza grupa obejmowała osoby po zakończeniu edukacji w wieku do trzydziestu lat, natomiast drugą grupę stanowiły osoby w wieku powyżej pięćdziesięciu lat. Warunkiem uczestnictwa było spełnienie kryterium wiekowego oraz posiadanie statusu osoby bezrobotnej. W badaniu wykorzystano głównie metody statystyczne oraz metodę kwestionariuszową, które polegały na przekazaniu uczestnikom specjalnie opracowanej ankiety. Głównym celem badania była identyfikacja podstawowych barier rozwoju utworzonych przedsiębiorstw oraz zweryfikowanie liczby przedsiębiorstw, które po zakończeniu czasu przewidzianego w projekcie, jako obowiązkowy zdecydowały się kontynuować działalność gospodarczą. Jednocześnie położono nacisk na wskazanie różnic $w$ podejściu do rozwoju oraz prowadzenia działalności gospodarczej w zależności od grupy wiekowej. Uzyskane wyniki pozwalają na wskazanie uwarunkowań rozwojowych przedsiębiorstw zakładanych przez osoby 50+ oraz osoby młode. Wyniki badania stanowią odmienną obserwację w stosunku do badań i wcześniejszych analiz, gdzie wykazywano, że to głównie osoby powyżej 50 roku życia charakteryzowały się większym ryzykiem niż osoby młode. Jednocześnie uzyskane wyniki mogą mieć zastosowanie do przyszłych programów dotyczących wspierania przedsiębiorczości osób wykluczonych, a także lepiej dopasować je do ich potrzeb. Należy zauważyć potrzebę przeprowadzenia szerszych analiz obejmujących większą liczbę uczestników projektów z różnych regionów.
\end{abstract}

Keywords: dotacje, pomoc UE, wzrost gospodarczy, nowe przedsiębiorstwa, mikroprzedsięborstwa 
